\title{
Documentation of Weeds Expressed with Sterility Symptoms in Pulse Growing Area
}

\author{
K. Kalaichelvi* and J. Prabhaharan \\ Agricultural College and Research Institute, Madurai-625 104, India \\ *Corresponding author
}

\begin{tabular}{l} 
K e y w o r d s \\
$\begin{array}{l}\text { Sterility symptoms } \\
\text { in weeds - } \\
\text { documentation }\end{array}$ \\
Article Info \\
$\begin{array}{l}\text { Accepted: } \\
17 \text { August } 2020 \\
\text { Available Online: } \\
10 \text { September } 2020\end{array}$ \\
\hline
\end{tabular}

\section{A B S T R A C T}

\section{Introduction}

Role of weeds/alternate hosts on the epidemiology of viral disease has been studied in case of many important viruses from India and abroad which are the major limiting factors to cultivation of important crops. Tomato leaf curl New Delhi virus
(ToLCNDV) was detected in sponge gourd, chilli, potato and tomato; and Ageratum enation virus (AEV) in black gram, $A$. conyzoides and $C$. bonplandianum samples. In phylogenetic analysis, ToLCNDV, and AEV isolates clustered in two distinct clades with their respective begomovirus isolates. This is the first record of tentative identification of 
AEV infecting black gram and $C$. bonplandianum in India (Mohammad Sajid Khan et al., 2014). Sida spp. are arguably the most abundant natural reservoirs for begomoviruses in several regions of the world (Frischmuth et al., 1997). For controlling virus infection, use of virus free planting materials, regular surveillance for disease symptoms at early stages of plants, followed by cleaning and removal of commonly growing weeds viz. Ageratum conyzoides, Acalypha indica, Croton bonplandianum, Eclipta prostrata, Physalis minima, Nicandra physaloides, Solanum nigrum, Datura stramonium, D. metel and other weeds (which act as potential reservoirs of begomovirus) from fields was found to be very effective (Prajapat et al., 2014).

Pulses especially black gram and greengram was severely infected with virus (Yellow Mosaic virus). Hence in the research block of pulses, Tamil Nadu Agricultural University, Coimbatore, a surveillance was made to document the weeds infected with sterility symptoms. Weeds namely Euphorbia geniculata, Parthenium hysterophorus, Phyllanthus niruri, Croton sparsiflorus and Cleome viscosa were reported with severe sterility symptoms and the infection were carried over seasons and found in large numbers.

\section{Materials and Methods}

Pulses especially black gram and greengram was severely infected with virus (Yellow Mosaic virus). Hence in the research block of pulses, Tamil Nadu Agricultural University, Coimbatore, a surveillance was made to document the weeds infected with sterility symptoms and some partial seed formation are also observed and the seeds from infected plants were collected for studying seed transmission. Seeds were collected form the infected plant but unfortunately there was poor germination under invitro study and could not be documented. Sterility documents were photographed and presented.

\section{Results and Discussion}

Weeds namely Euphorbia geniculata, Parthenium hysterophorus, Phyllanthus niruri, Croton sparsiflorus and Cleome viscosa were reported with severe sterility symptoms and the infection were carried over seasons. Euphorbia geniculata was observed with similar symptom as developed by the Black gram and Green gram Yellow Mosaic virus. Already for powdery mildew this weed is the important host and now this is observed with sterility symptoms similar to Yellow Mosaic Virus (Fig. 1-4).

Fig.1

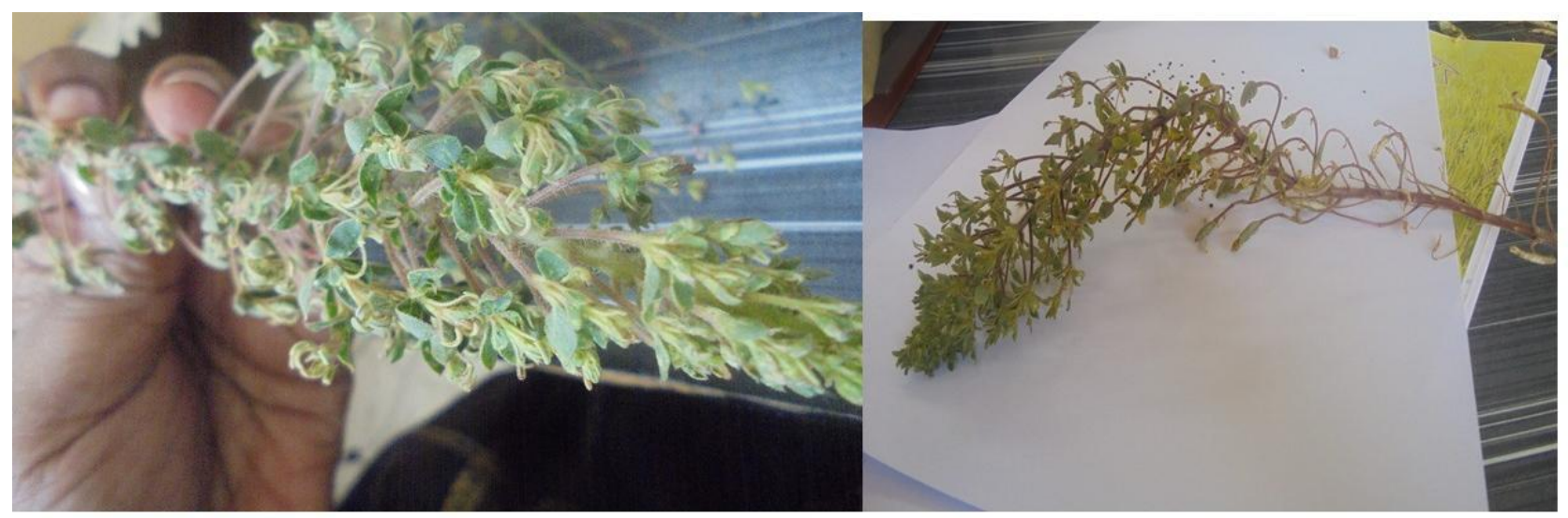

Cleome viscosa - sterility - flowers modified in to leafy structure 
Fig.2

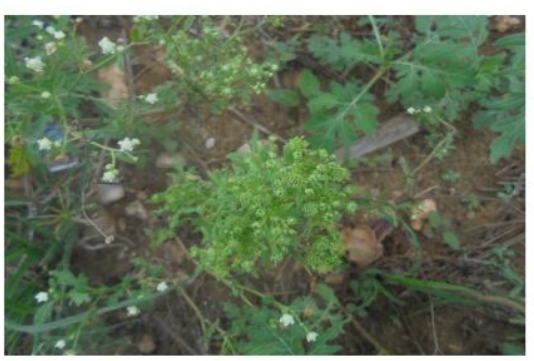

Parthenium hysterophorus - sterility infection varies from severe to mild

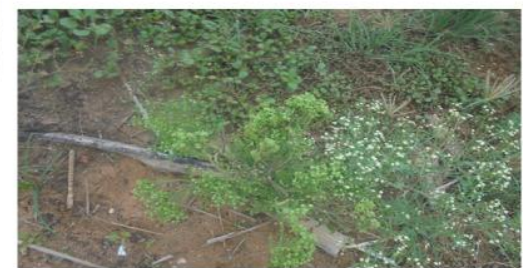

Fig.3

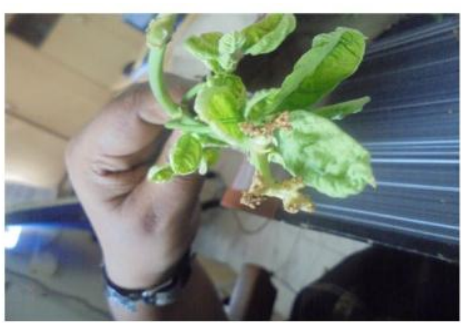

Euphorbia geniculata - sterility - modified floral and fruiting parts and the same symptom was identified in blackgram

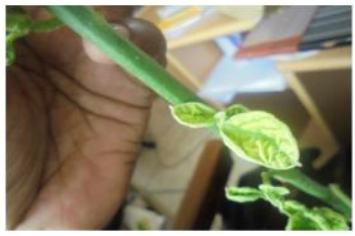

Euphorbia geniculata - Leaf crinkling with chlorosis

Fig.4

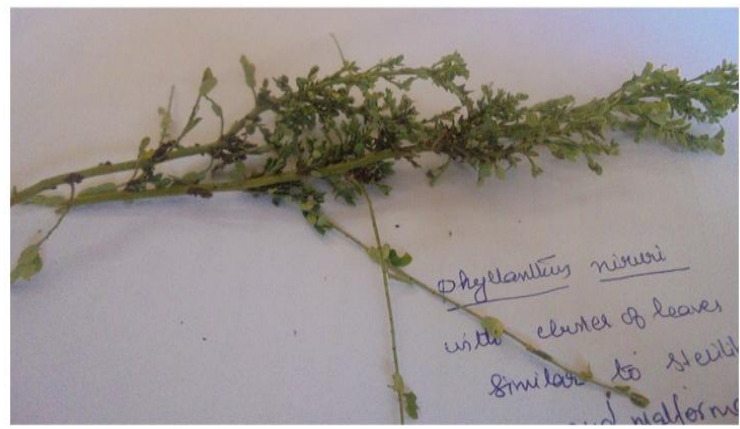

Phyllnathus niruri-sterility- floral modification in to cluster of leaves

The fruiting bodies are turning in to a claw like structure with severe malformation depicting the same in blackgram and Euphorbia geniculata (Fig. 1). The most hardy Pathenium hysterophorus also reported with sterility symptom due to virus infection. This is in accordance with the report of Prajapat et al., (2014) that Croton 
bonplandianum to be the host of Tomato leaf curl New Delhi virus (ToLCNDV) and Parthenium hysterophorus was found to host of Tomato leaf curl Karnataka virus (ToLCKV).

Phyllanthus niruri, Croton sparsiflorus also observed with sterility symptoms. Cleome viscosa is observed with severe sterility similar to phyllody in the Research block and as well as all the parts of Tamil Nadu and this is commonly occurring and spreads in North and South Tamil Nadu. Hence these weeds should be watched for virus transmission to the crops as they persist over generation and the transmission by seeds also to be verified. Sida sp. and Abutilon indicum as alternate hosts of Cotton leaf curl virus in Punjab (Singh et al., 1994). Valand and Muniyappa, 1992 reported Nicotiana plumbaginifolia, Physalis minima, Coccinia grandis, Solanum nigrum, Momordica charantia (wild), Sorghum vulgare (widely growing) and Luffa spp. weeds have been found to be the hosts of geminivirus in north India.

Therefore, these weeds (Euphorbia geniculata, Parthenium hysterophorus, Phyllanthus niruri, Croton sparsiflorus and Cleome viscosa) must be removed from and around the agricultural crop fields especially in pulse growing areas to minimize the source of reservoirs of many begomoviruses which also provide the shelter to whitefly, the known vector for transmission of a variety of begomoviruses.

\section{References}

Frischmuth T., Engel M., Lauster S., Jeske H. 1997 Nucleotide sequence evidence for the occurrence of three distinct whitefly-transmitted, Sida-infecting bipartite geminiviruses in Central America. Journal of General Virology, 78, 2675-2682.

Mohammad Sajid Khan, Ajay Kumar Tiwari, Shri Krishna Raj, Ashish Srivastava, Sang Hye Ji and Se Chul Chun, 2014. Molecular epidemiology of begomoviruses occurring on some vegetables, grain legume and weed species in the Terai belt of north India, Journal of Plant Diseases and Protection Vol. 121, No. 2: pp. 53-57.

Prajapat, R., A. Marwal\& R.K. Gaur. 2014. Begomovirus associated with alternative host weeds: a critical appraisal, Archives of Phytopathology and Plant Protection, 47:2, 157170, DOI: $10.1080 / 03235408.2013 .805$ 497

Singh J, Sohi AS, Mann HS, Kapoor SP, 1994. Studies on whitefly Bemisiatabaci (Genn.) transmitted cotton leaf curl virus disease in Punjab. J Insect Sci 7: 194-198.

Valand GB, Muniyappa V, 1992. Epidemiology of tobaco leaf curl virus in India. Ann Appl Biol 120: 257-267.

\section{How to cite this article:}

Kalaichelvi, K. and Prabhaharan, J. 2020. Documentation of Weeds Expressed with Sterility Symptoms in Pulse Growing Area. Int.J.Curr.Microbiol.App.Sci. 9(09): 2390-2393. doi: https://doi.org/10.20546/ijcmas.2020.909.298 